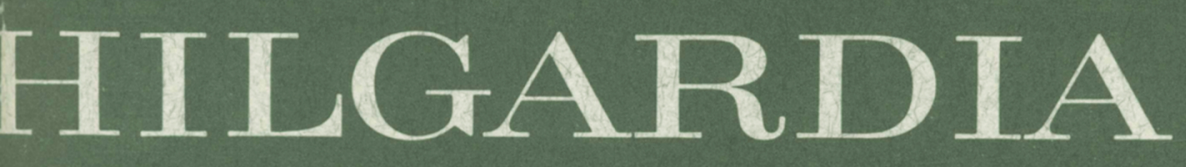

JOURNAL OF AGRICULTURAL SCIENCE PUBLISHED BY HE CALIFORNIA AGRICULTURAL EXPERIMENTSTATION

Volume 35, Number $21 \cdot$ October, 1964

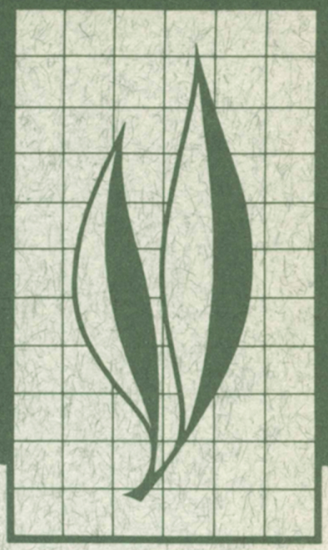

\title{
Pythiaceous Fungi
}

\section{and Plant-Parasitic Nematodes}

\section{in California Pear Orchards}

I. Occurrence and Pathogenicity of

Pythiaceous Fungi in

\section{Orchard Soils}

Carl W. Nichols, S. M. Garnsey, R. L. Rackham,

S. M. Gotan, and C. N. Mahannah

II. Incidence and Distribution of Parasitic Nematodes in Orchard Soils

Alex M. French, B. F. Lownsbery, S. M. Ayoub, A. C. Weiner, and N. El-Gholl

III. Effect of Reduction of Nematode Populations by Soil Fumigation on Subsequent Growth of Pear Seedlings

B. F. Lownsbery, J. T. Mitchell, and S. M. Paracer 


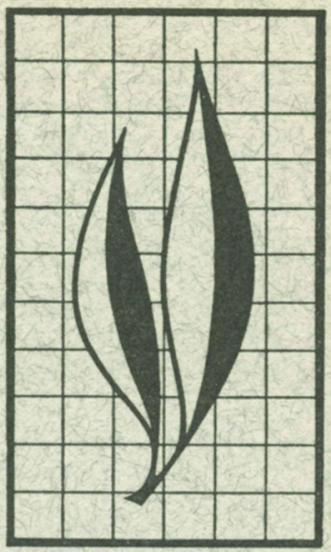

Pythiaceous Fungi and Plant-Parasitic Nematodes in California Pear Orchards

I. During a year's survey of 126 California pear orchards with varying degrees of pear-decline damage, a total of 3,586 isolates of soil-borne fungi of the genera Pbytophthora and Pythium were recovered, and, where possible, identified as to species.

A direct relationship was found between the severity of pear-decline damage in an orchard and the percentage of isolates from the orchard that were Pythium spp.; and a corresponding inverse relationship between peardecline damage severity and the percentage of isolates that were Phytophthora spp.

Isolates of Phytophthora cactorum and $P$. cryptogea were found to be pathogenic on Pyrus communis L. hort. var. Winter Nelis and Pyrus serotina Rehd. seedlings. These pathogens were found infrequently, and it was concluded that pythiaceous fungi were not the primary cause of pear decline.

\section{THE AUTHORS}

I. Carl W. Nichols is Plant Pathologist and Program Supervisor of Special Projects, Bureau of Plant Pathology, California Department of Agriculture, Sacramento. S. M. Garnsey was formerly Research Assistant, Department of Plant Pathology, Davis, and is now Plant Pathologist at the Horticultural Field Station, U.S. Department of Agriculture, Orlando, Florida; R. L. Rackham was formerly Extension Technologist in the Agricultural Extension Service, Davis, and is now a University of California Farm Advisor in the Agricultural Extension Service, San Bernardino County; S. M. Gotan is Plant Pathologist, Bureau of Plant Pathology, California Department of Agriculture, Sacramento; C. N. Mahannah is Research Assistant, Department of Irrigation, Davis.

II. Alex M. French is Program Supervisor of Plant Nematology, Bureau of Plant Pathology, California Department of Agriculture, Sacramento. S. M. Ayoub and A. C. Weiner are Plant Nematologists, Bureau of Plant Pathology, California Department of Agriculture, Sacramento. N. El-Gholl is now Plant Pathologist, Riverside County Department of Agriculture, Riverside.

III. B. F. Lownsbery is Associate Nematologist, in the Experiment Station, Davis. J. T. Mitchell is Laboratory Technician and S. M. Paracer is a graduate student in the Department of Nematology, Davis. 


\section{Occurrence and Pathogenicity of Pythiaceous Fungi in Orchard Soils ${ }^{1}$}

\section{INTRODUCTION}

The RAPID SPREAD of pear decline in California, which began in 1959 (Nichols et al., 1960), and the concurrent lack of knowledge of its cause instigated a broad-scale research program by federal, state, county, and private agencies for the study of all aspects of the disease. An integral part of this program was an annual survey of certain randomly selected pear orchards (Rackham et al., 1964). This survey began in 1960 and continued through the 1962 growing season. Approximately 14,000 trees, representing 126 orchards in 18 counties, were surveyed. The survey was expanded in the spring of 1961 to determine whether certain root pathogensnamely, fungi in the genera Pythium and Phytophthora and plant-parasitic nematodes-had a role in pear-decline development as: (1) a primary causal agent or agents; (2) contributing secondary or stress factors; or (3) the cause of one or more independent disease situations readily confused with the pear-decline syndrome.

Personnel of the California Department of Agriculture, Bureau of Plant Pathology, were responsible for the collection of soil samples, extraction and identification of plant-parasitic nema- todes, and isolation of fungi into pure culture. Personnel of the University of California Nematology, Plant Pathology, and Irrigation Departments and Agricultural Extension Service were responsible for additional nematode and all fungus identifications as well as all pathogenicity studies.

This paper is primarily concerned with the distribution and pathogenicity of certain Pythium and Phytophthora species in California pear soils. Other papers (French et al., 1964; Lownsbery et al., 1964) report the distribution and effects of plant-parasitic nematodes in California pear soils.

Several factors led to the selection of the pythiaceous fungi for study as possible causes or contributors to the peardecline disorder. The lack or death of feeder roots on pear-decline-affected trees (Nichols et al., 1960) suggested that the roots may have been killed by soil-inhabiting root parasites. Floodirrigation practices in some pear-growing areas in California, and shallow soil conditions with accompanying waterlogged pockets of soil in other such areas, often produced conditions very favorable to the development of the pythiaceous or "water-mold" fungi.

\footnotetext{
${ }^{1}$ Submitted for publication December 26, 1963.
} 
Cameron (1960), McIntosh (1960), Newhook (1957), and Sprague (1957) had found certain of the pythiaceous fungi to be pathogenic to pear roots. Newhook (1957) commented on the similarity between the symptoms of the New Zealand Pythium disease of pear and the moria disease of pear in Italy (Baldacei et al., 1949), which is now considered to be the same as pear decline (Shalla et al., 1961). Sprague (1957) warned that excess water and root necrosis caused by Pythium debaryanum Hesse should not be overlooked in the search for the causes of pear decline. McIntosh (1960) suggested that root damage by $P h y$ tophthora cactorum (Leb. and Cohn) Schroet. might be implicated in the development of pear decline in British Columbia. After the California investigation began, Cameron (1962) reported that Phytophthora cinnamomi Rands and Phytophthora cactorum (Leb. and Cohn) Schroet. could kill the roots of pear seedlings but concluded that Phytophthora spp. are not the primary cause of pear decline.

Collapse or decline of woody plants other than pear, induced by pythiaceous root rots, have been reported on avocado (Wager, 1942a; Klotz and Sokoloff, 1943; Zentmyer and Richards, 1952), citrus (Wager, 1942b; Klotz and Sokoloff, 1943; Klotz et al., 1958), and grape in California (Chiarappa, 1959); on pine in the southeastern United States (Campbell, 1948) and in New Zealand (Newhook, 1959; Sutherland and Newhook, 1959) ; and on Lawson cypress and other ornamentals in Oregon (Torgeson, 1951; Torgeson, Young, and Milbrath, 1954; Tucker and Milbrath, 1942).

Many Phytophthora spp. have been reported responsible for stem and crown rots of pears and other trees throughout the world (Anon., 1942-1963, 1960; Tucker, 1933). Many of these diseases occur in California on young trees and nursery stock of almond, apple, apricot, cherry, peach, pear, and plum (Hunt, 1921; E. Smith, 1915; R. Smith and E. Smith, 1925; R. Smith, 1941); and on mature plants of avocado (Fawcett, 1916), citrus (Fawcett, 1913, 1915, 1920, 1936), loquat (Miller, 1942), peach, prune, walnut (C. Smith and Barrett, 1930), and Washington palm (Darley and Wilbur, 1953).

\section{MATERIALS AND METHODS}

\section{Soil sampling}

Soil samples were collected from April 1, 1961, through March 31, 1962, from 126 randomly selected pear orchards in all the pear-growing districts of the state (fig. 1), representing all the major pear-growing soil types. This was the only period during the California pear-decline survey of 1960, 1961 and 1962 (Rackham et al., 1964) when a systematic sampling of pear soil was made, and all soil samples to which reference is made in this paper are those collected during this 12-month period.

One composite soil sample was collected each month from selected rows in each orchard. Usually the rows sampled were the center row running the length of the orchard and the center row runing the width of the orchard. Every tenth tree in smaller orchards and every twentieth tree in larger orchards was sampled. The soil was collected from around the same trees each month and was taken at a depth of about one foot in the area directly underneath the drip line of the trees. The composited soil samples were placed directly in polyethylene bags and were kept in a portable icebox while being transported from the orchard to the laboratory. They were held in a refrigerator at about $2^{\circ}$ to $5^{\circ} \mathrm{C}$ until processed. It was sometimes necessary to store the samples 


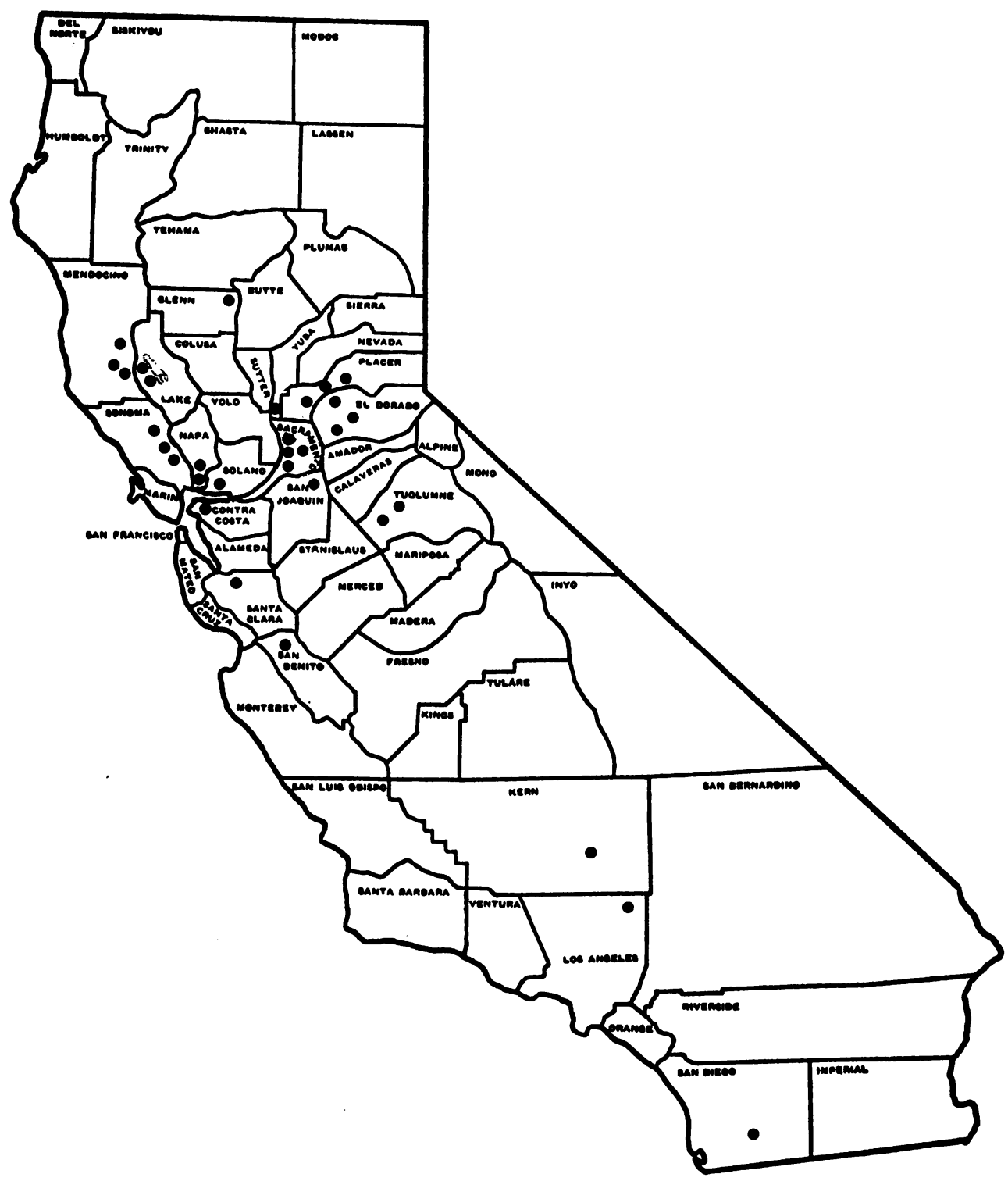

Fig. $1, \bullet=$ pear-growing areas in California from which soil samples were taken.

as long as two months; however, the average storage time was about six weeks. Most of the orchards from which a soil sample was taken were rated for the severity of pear-decline damage during the 1960, 1961, 1962 California peardecline survey (Rackham et al., 1964). The individual trees in the sampled rows ware evaluated as to severity of pear-decline damage on a 1 to 5 "peardecline rating" scale (similar to that of Woodbridge et al., 1957) as follows:

$1=$ no growth reduction, tree apparently normal

$2=$ shoot growth somewhat stunted $3=$ shoot growth definitely limited

$4=$ no shoot growth and some reduction of amount of foliage 
$5=$ no shoot growth, very sparse foliage, with some trees appearing nearly dead; or trees with varying amounts of shoot growth and foliage that suddenly wilted and appeared dead.

An index of the severity of peardecline damage (decline index) in each orchard was obtained by determining the average pear-decline rating for all the trees rated in the orchard. The decline index for each county was calculated by the same method but included all the trees rated in a given county. In this report only the 1961 decline indexes are used and orchards or counties with decline indexes of 1 to 1.4 were considered to have light damage; those in the range of 1.4 to 1.9 to have moderate damage; and those above 1.9 to have severe damage.

Each composite soil sample was divided and processed for the determination of plant-parasitic nematodes and fungi of the genera Pythium and Phytophthora. Results of the nematode examinations are reported elsewhere in this issue (French et al., pp 603-10; Lownsbery et al., 611-14).

\section{Isolation}

The pythiaceous fungi were isolated from the soil samples by using adaptations of "trap" techniques described by Anderson (1951), Campbell (1949), Eckert and Tsao (1960), Klotz and DeWolfe (1958), Newhook (1959), Tucker (1931), and Zentmyer et al. (1960). Approximately 100 ce of each soil sample were placed in each of three or four 8-ounce wax-coated cartons, forming a soil layer about $11 / 2$ inches deep. Distilled water was added to each carton to produce a 1 -inch layer of free water on the surface of the soil. The cartons were then incubated for 24 hours at room temperature. An apple, avocado, lemon or pear fruit, blemishfree and held in running tap water for two hours prior to use, was then placed on the soil in each carton as a trap. Avocado fruits were not used for the soil samples collected during the months of July through October, 1961, because the only satisfactory variety, Fuerte (Zentmyer et al., 1960), was not available at that time. Seedlings of Winter Nelis pears were also used 'as traps, beginning with the collections made during June, 1961; and apple seedlings of various commercial varieties were used, beginning with the collections made during October, 1961. These seedlings were obtained from seeds washed in running tap water for two hours and removed to moist paper towels to germinate. The seedlings, selected to be free from any stem discolorations, were held until used as traps, in glass beakers containing a small amount of distilled water, on a laboratory window sill, where they received indirect sunlight. Seedlings one or two weeks old were placed in the cartons with their respective fruit traps. Apple, pear, and lemon fruits were used for all samples. The surfaces of the apple and lemon fruits obtained from commercial markets were lightly scraped to remove the protective wax which apparently inhibits fungus penetration.

Soil and traps were incubated at about $25^{\circ} \mathrm{C}$ for 96 hours. Isolations were made from infected areas of fruit or seedlings to cornmeal agar. Contaminants were eliminated by further transfers to Difco cornmeal or CM3P agars (Eckert and Tsao, 1962), and pure cultures were stored on cornmeal agar slants.

\section{Culture identification}

A total of 3,586 cultures were obtained in this survey, a fact which made it necessary to develop relatively rapid growth-typing procedures for subsequent identification studies. Cultures with similar growth rates, gross colony morphology, and reproductive structures were placed in a single group. Each group was given a growth type 
(GT) code number, pending further identification. This process is referred to in this paper as "growth-typing."

Each culture was transferred to four petri dishes for growth-typing. Two contained PDA, one contained water agar, and one contained differential media ("dif"). A dif agar plate was made by placing four 8-mm discs, one but they were formed regularly on infested alfalfa stems or lima bean agar placed either in tap water or Hoagland's solution.

The data for each isolate were recorded on a Unisort analysis card for rapid data processing. The data recorded on the cards included growth type, sporangia type, oospore type,

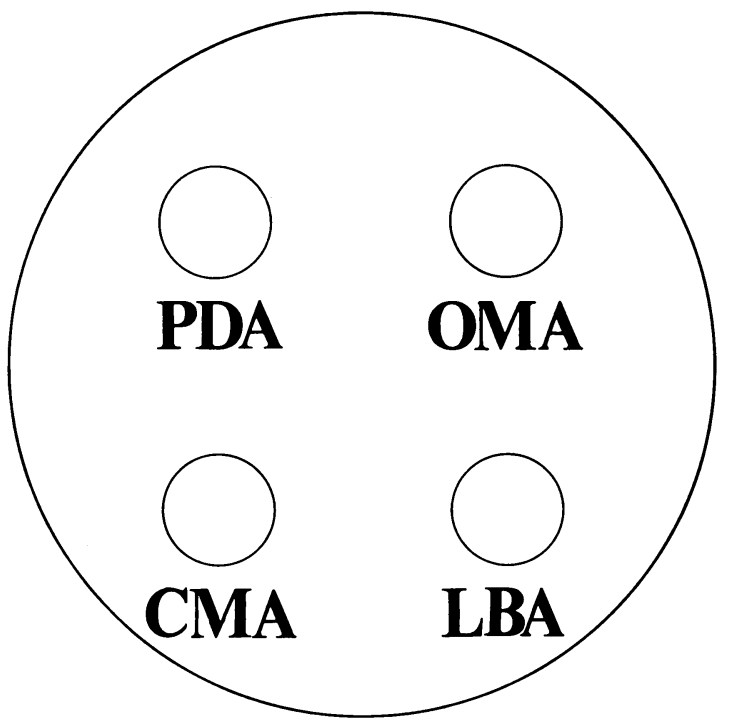

Fig. 2. Differential media (dif) plate containing 8-mm discs of potato-dextrose, oatmeal, lima bean, and cornmeal agars, surrounded by water agar.

each of potato-dextrose, oatmeal, lima bean and cornmeal agars, in a sterile petri plate (fig. 2). Water agar was added to the top level of the discs. Cultures were placed on each of the four discs. Dif agar plates provided substrate gradients and nutritional variety to encourage the formation of reproductive structures.

The agar media used in these studies were: (1) PDA containing 2.0 per cent potato extract, 1.0 per cent dextrose and 1.5 per cent agar; (2) oatmeal agar containing 4.0 per cent oatmeal and 2.0 per cent agar; (3) Difco lima bean agar; (4) Difco cornmeal agar; and (5) water agar containing 1.5 to 2.0 per cent agar.

Sporangia for certain growth types were rarely observed in agar culture, identification, trap type, month of collection, property number and county.

The colony diameters were measured on the PDA and water agar plates after four days' incubation at $21^{\circ} \mathrm{C}$. Determination of the gross colony morphology on the PDA plate, including the amount of aerial mycelium, its pattern and the type of zonation, was also made at four days. The dif plate was incubated at $21^{\circ} \mathrm{C}$ for 12 to 21 days and then observed microscopically for reproductive structures and mycelial characteristics. Notation was made on the size and general morphology of the sporangia when present and the method of sporangial germination, if observed. Oospores present were checked for size, morphology, and position of antheridial attachment. 
The size and branching angle of the mycelium were observed and any hyphal swellings or vesicles were noted.

After growth-typing, 10 per cent of the cultures from growth types recovered most frequently and 50 to 80 per cent of those found infrequently were transferred to fresh cornmeal agar slants and saved for taxonomic study and pathogenicity tests. Representative samples were selected from the type of traps and counties represented within each growth type.

Identification of each growth type was carried as far as possible by detailed study of representative isolates. Optimum growth temperatures were determined in dam tubes. Sporulation on a variety of media, including hemp seed agar and alfalfa stems (Klotz and DeWolfe, 1960), was observed. Keys and descriptions by Middleton (1943), Waterhouse (1956), and Waterhouse and Blackwell (1954) were used for identification.

\section{Patbogenicity tests in nutrient solution}

All pathogenicity tests were made in a greenhouse which was maintained as far as possible at 21 to $24^{\circ} \mathrm{C}$ in the winter and at 24 to $27^{\circ} \mathrm{C}$ in the summer. The growth medium was number one Hoagland's solution in 3-gallon glazed crocks (Hoagland and Arnon, 1950). Seedlings were supported by a masonite template with ten $1 \times 5 \mathrm{~cm}$ slots cut radially around the outside. This template was coated with an inert plastic resin. Seedlings were held in place with small rolls of sterilized cotton. Aeration was provided by a small air stone of the type commonly available for aquarium use. This air stone was centered in the crock to provide uniform aeration. Compressed air was washed by bubbling it through a closed flask of water, after which it was transported through a manifold system to individual crocks. The air supply was regulated by valves, so that gentle bubbling occurred in each crock. Vigorous bubbling was avoided to prevent contamination by splashing.

Five seedlings each of Pyrus serotina Rehd. and Pyrus communis L. var. Winter Nelis were suspended in each test crock. These seedlings were grown from seed stratified in a sterilized mixture of moist sand and peat for at least six weeks at $2^{\circ} \mathrm{C}$. Stratified seeds were planted as needed in 8-inch clay pots containing a sterile sandy soil. After four weeks the seedlings were removed from the soil, washed thoroughly, and dipped in a 1 to 20 dilution of commercial sodium hypochlorite for two minutes. They were then placed in the test crocks containing clean nutrient solution. After they had established a good fibrous root system 6 to 10 inches long, they were inoculated with one isolate per crock.

Inoculum was grown on alfalfa stems, using the technique of Klotz and DeWolfe (1960). A bundle of infected stems was rinsed with sterile water and suspended in the middle of the crock. Sterile alfalfa stems were suspended in control crocks.

Roots were checked each day for lesions, and after seven days the plants were removed from the crocks and rated for root rot on a scale of one to four as follows:

$1=$ no rot

$2=$ light rot; a few lesions were present throughout the root system, but most roots appeared white and healthy.

$3=$ moderate rot; all roots were attacked and rotted initially, but recovery appeared possible because new rootlets without infection were produced after one week.

$4=$ severe rot; all roots were attacked, appeared somewhat slimy, were brown to black, plant leaves wilted, and no regrowth of roots occurred. 
Excised root pieces were surfacesterilized and placed on CM3P agar (Eckert and Tsao, 1962).

\section{Pathogenicity tests in potted soil}

Soil pathogenicity tests were made in the same greenhouse used for the nutrient solution tests. Inoculum substrate was prepared by adding $30 \mathrm{ml}$ of water to a flask containing $4 \mathrm{gm}$ of wheat seed, $4 \mathrm{gm}$ of oat seed, and $2 \mathrm{gm}$ of ground-up alfalfa stems. The flasks were plugged with cotton and autoclaved for $30 \mathrm{~min}$. The substrate was inoculated and incubated at $21^{\circ} \mathrm{C}$ for 10 days. The medium was stirred by shaking the flask every 3 days.

Five Winter Nelis seeds and 5 Pyrus serotina seeds were planted in 6-inch clay pots containing a sandy soil mixture and were subsequently thinned to four uniform seedlings of each variety and species. When the seedlings had grown 4 to 6 inches in height, one flask of inoculum was stirred into the top soil of each pot. Sterile wheat-oatalfalfa medium was added to one set of control plants and nothing was added to other controls. All pots were thoroughly irrigated after inoculation, and adequate moisture for good plant growth was maintained thereafter.

After five weeks the plants were removed from each pot. The roots were carefully washed and examined for lesions. Excised root pieces were surface-sterilized and placed on CM3P agar to test for recovery of the inoculum (Eckert and Tsao, 1962).

Duplicate inoculations were made in some of the tests. One pot received normal irrigation and one was set in 3 inches of free water for seven days after inoculation. The soaked pots were then removed to dry saucers on a bench for the remaining four weeks of the test.

\section{RESULTS}

\section{Growth types}

The 1,512 soil samples processed in this survey yielded 3,586 cultures of various Pythium and Phytophthora species. Examination of the initial 500 to 600 cultures revealed that almost all the cultures could be placed in 10 groups on the basis of similarity of growth rate (table 1), colony morphology (figs. 3 and 4), morphology of reproductive structures (figs. 5 and 6 ), and hyphal character.

\section{Identification of growth types}

$G T-1$. Cultures in GT-1 fit closely the description of Pythium vexans de Bary given by Middleton (1943) in regard to oospore morphology, method of antheridium attachment, sporangial size and shape, gross colony growth habit, and cardinal growth temperatures. Typing was based on colony growth pattern and sporangial morphology (figs. 3 and 5 ).

$G T$-2. The distinct papillate shape of the sporangia (fig. 5), the sympodial character of the sporangiophore (Blackwell, 1949), the paragynous nature of the antheridia, and the ready production of these fruiting bodies on agar media led to the identification of GT-2 cultures as Phytophthora cactorum (Leb. and Cohn) Schroet. A limited smooth colony (fig. 3, table 1) and the abundant production of characteristic sporangia and oospores (fig. 5) were the typing features for GT-2.

GT-3. A slightly zonate, limited colony lacking aerial mycelium (fig. 3, table 1), the presence of hyphal swellings, proliferating sporangial development (fig. 5), and lack of oospores distinguished the GT-3 group. This growth type posed a continual and, to date, unsolved taxonomic problem. Although easily identified as belonging to the genus Phytophthora, no species identification could be made. All GT-3 cultures resembled our isolates of $P$. mega- 


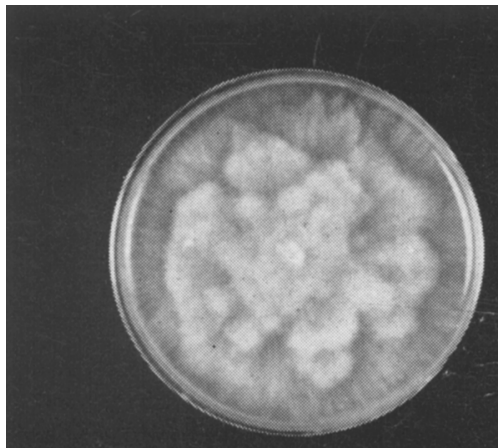

1

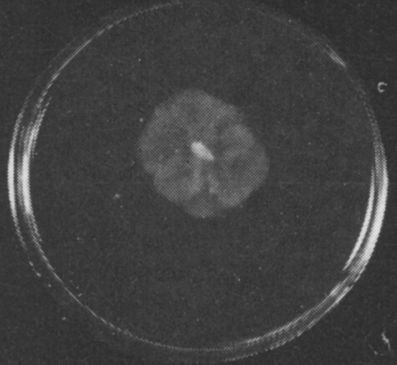

3

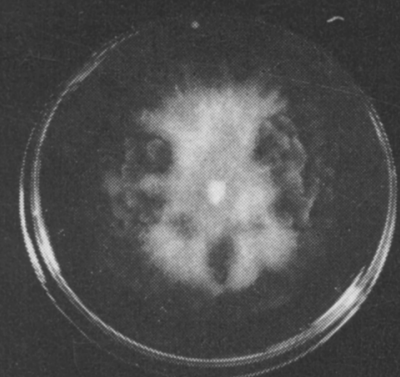

$5 \mathrm{~A}$

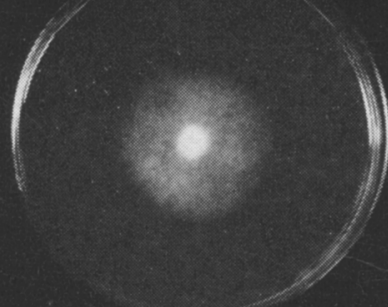

2

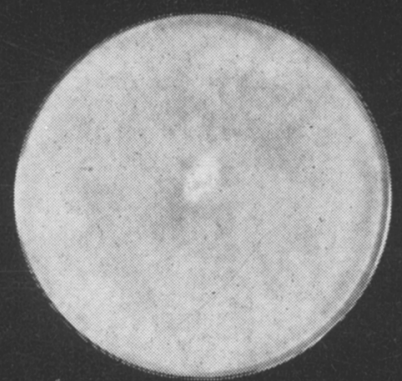

4

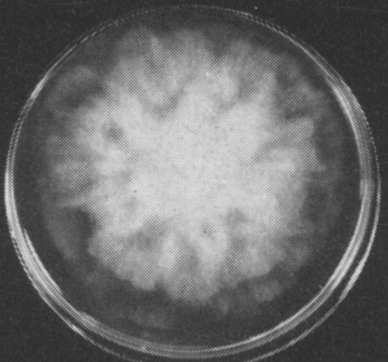

5 B

Fig. 3. Growth types 1 through $5 \mathrm{~B}$, grown on $\mathrm{PDA}$ at $21^{\circ} \mathrm{C}$ for four days.

sperma Drechsl. ( $\mathrm{GT}=8$ ) in sporangial formation and morphology on alfalfa stems (fig. 5), and in the formation of hyphal swellings. They differed, however, in growth rate, colony morphology (table 1, figs. 3 and 4) and, most importantly, in their inability to produce oospores. Limited mating trials have been unsuccessful. Until definite evidence is available on oospore production and morphology, it would seem advisable to designate GT-3 cultures only as a Phytophthora species.

$G T-4$. The characteristic features for 


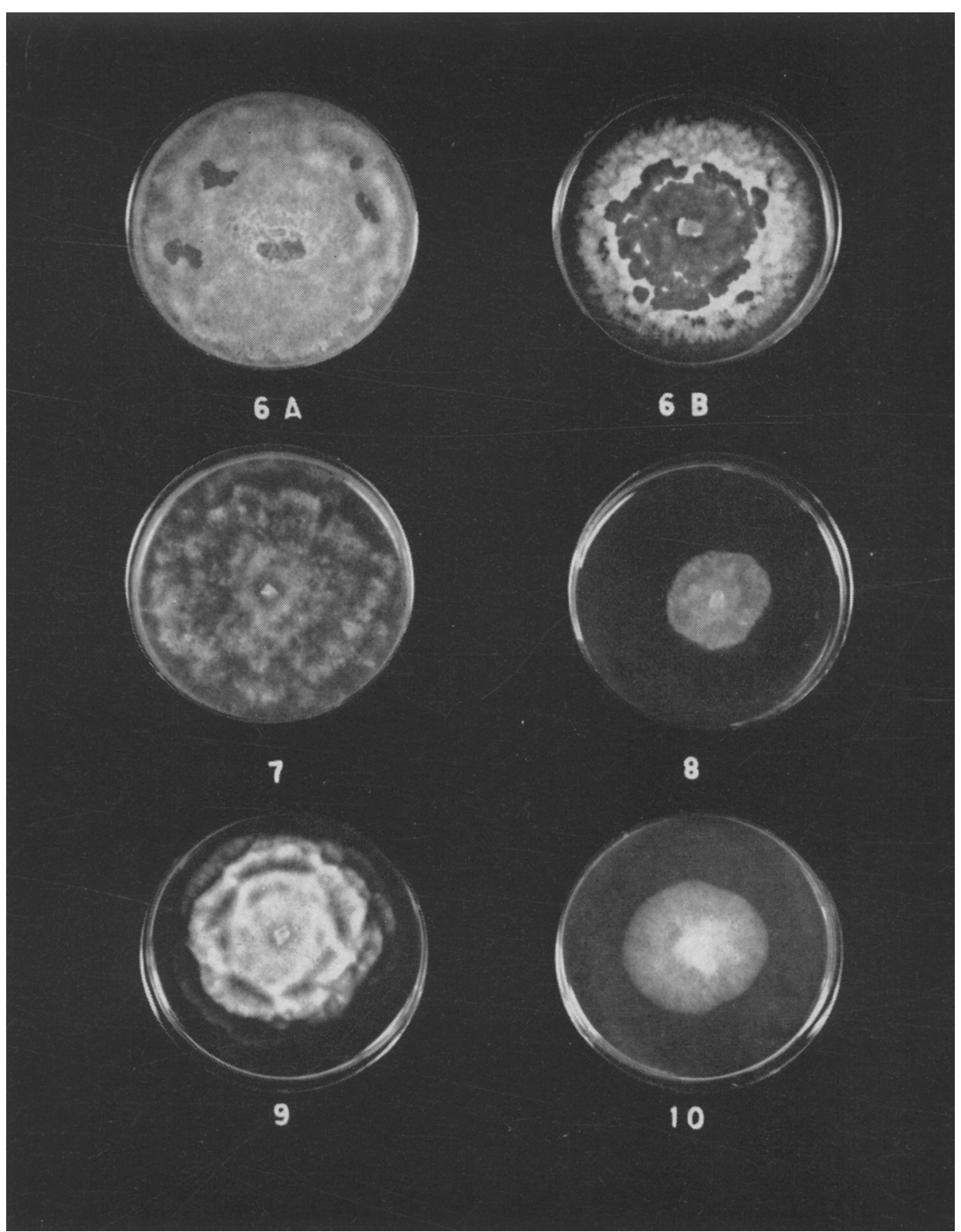

Fig. 4. Growth types $6 \mathrm{~A}$ through 10 , grown on PDA at $21^{\circ} \mathrm{C}$ for four days.

most GT-4 cultures were spherical sporangia and apleurotic oospores in dif agar media (fig. 5, table 2) and a rapidly growing, fluffy, nonzonate colony habit (fig. 3, table 1). Most of the GT- 4 cultures have been classified as Pythium ultimum Trow. This de- termination was based on the presence of spherical sporangia, 20 to $30 \mu$ in diameter (fig. 5, table 2), which germinated directly both on agar and in various solution cultures; a rapid nonzonate growth habit (fig. 3); and the morphology of the antheridia. It 
TABLE 1

MACROSCOPIC CHARACTERISTICS OF GROWTH TYPES

INCUBATED FOR 4 DAYS AT $21^{\circ} \mathrm{C}$

\begin{tabular}{|c|c|c|c|c|c|c|}
\hline \multirow{3}{*}{$\begin{array}{l}\text { Growth } \\
\text { type }\end{array}$} & \multirow{3}{*}{ Identification } & \multicolumn{4}{|c|}{ Colony diameter } & \multirow{3}{*}{$\begin{array}{l}\text { Colony growth-type } \\
\text { characteristics }\end{array}$} \\
\hline & & \multicolumn{2}{|c|}{ PDA } & \multicolumn{2}{|c|}{ Water agar } & \\
\hline & & Range & Av. & Range & Av. & \\
\hline $1 \ldots$ & Pythium vexans & $\underset{56-90}{m m}$ & $\begin{array}{r}m m \\
82\end{array}$ & $\begin{array}{c}m m \\
40-90\end{array}$ & $\begin{array}{r}m m \\
55\end{array}$ & Radially lobed, zonate \\
\hline $2 \ldots$ & Phytophthora cactorum & $16-37$ & 27 & 6-15 & 12 & $\begin{array}{l}\text { Nonzonate; smooth, velvety aerial } \\
\text { mycelium }\end{array}$ \\
\hline $3 \ldots \ldots$ & Phytophthora sp.* & $21-60$ & 32 & $8-50$ & 33 & Irregular, sparse aerial mycelium \\
\hline $4 \ldots \ldots \ldots$ & Pythium ultimum $\dagger$ & $>90$ & $>90$ & $>90$ & $>90$ & $\begin{array}{l}\text { Nonzonate; smooth, cottony aerial } \\
\text { mycelium }\end{array}$ \\
\hline $5 \ldots$ & Pythium sp. & $30-90$ & 61 & $34-85$ & 53 & Broadly lobed, often sectored \\
\hline $6 \ldots$ & Pythium sp. & $>90$ & $>90$ & $70-90$ & 89 & $\begin{array}{l}\text { Light to distinct concentric zona- } \\
\text { tion; central aerial mycelium } \\
\text { often collapsed }\end{array}$ \\
\hline $7 \ldots$ & Pythium acanthicum & $70-90$ & 85 & $54-90$ & 74 & Sparse, frosty growth \\
\hline $8 \ldots$ & Phytophthora megasperma & $25-54$ & 41 & $7-46$ & 36 & $\begin{array}{l}\text { Nonzonate; considerable frosty } \\
\text { aerial mycelium }\end{array}$ \\
\hline $9 \ldots$ & Pythium sp.* & $51-75$ & 64 & $31-55$ & 49 & Shell-like sectoring, sharply radial \\
\hline $10 \ldots$. & Phytophthora cryptogea & $37-43$ & 42 & $15-37$ & 31 & $\begin{array}{l}\text { Nonzonate; moderate aerial my- } \\
\text { celium }\end{array}$ \\
\hline
\end{tabular}

* It is possible that more than one species is represented by these growth types since oospores were not produced. $58 \theta^{+}$

is possible that some isolates of $P$. debaryanum Hesse were recovered and have been included in this group, since this species closely resembles $P$. ultimum in morphological detail. It was not possible to conduct sporangial germination tests on all the isolates typed because of their quantity (table $3)$. The major criteria for separation of $P$. ultimum and $P$. debaryanumthe typical method of sporangial germination and the number and morphology of the antheridia-are variable (Middleton, 1943, 1952), and separation of the two species would have been of questionable value.

Lobate sporangia occasionally were noted in some GT-4 cultures throughout the typing process (fig. 5). Subsequent taxonomic studies indicated that these were of the Pythium aphanidermatum Edson type. These constituted 8.4 per cent of the GT-4 group.

$G T-5$. Cultures placed in GT-5 were identified only as a Pythium sp., since these isolates consistently lacked oospores. Large spherical sporangia
35 to $40 \mu$ in diameter were produced on dif media plates (fig. 5, table 2). Cultures in this group formed a broadly lobed colony on PDA that sometimes contained sectors with small shell-like lobes (fig. 3).

$G T-6$. The isolates placed in GT-6 were also identified only as a Pythium sp. All the isolates produced filamentous sporangia, which germinated indirectly by vesicle formation and subsequent zoospore release when infested alfalfa stems or bits of lima bean agar were flooded with Hoagland's solution (fig. $6)$. The phenomenon was quite distinctive, readily discernible microscopically, and common to all GT-6 cultures examined in this manner. No oospore formation was observed for any isolate in this group. Typing characters were a pattern of mild to distinct concentric zonation, with the frequent collapse of the central aerial mycelium (fig. 4) and the lack of observable fruiting structures on dif plates.

GT-7. The GT-7 isolates were identified microscopically as Pythium acan- 
TABLE 2

MICROSCOPIC CHARACTERISTICS OF GROWTH TYPES INCUBATED FOR 12 TO 21 DAYS AT $21^{\circ} \mathrm{C}$

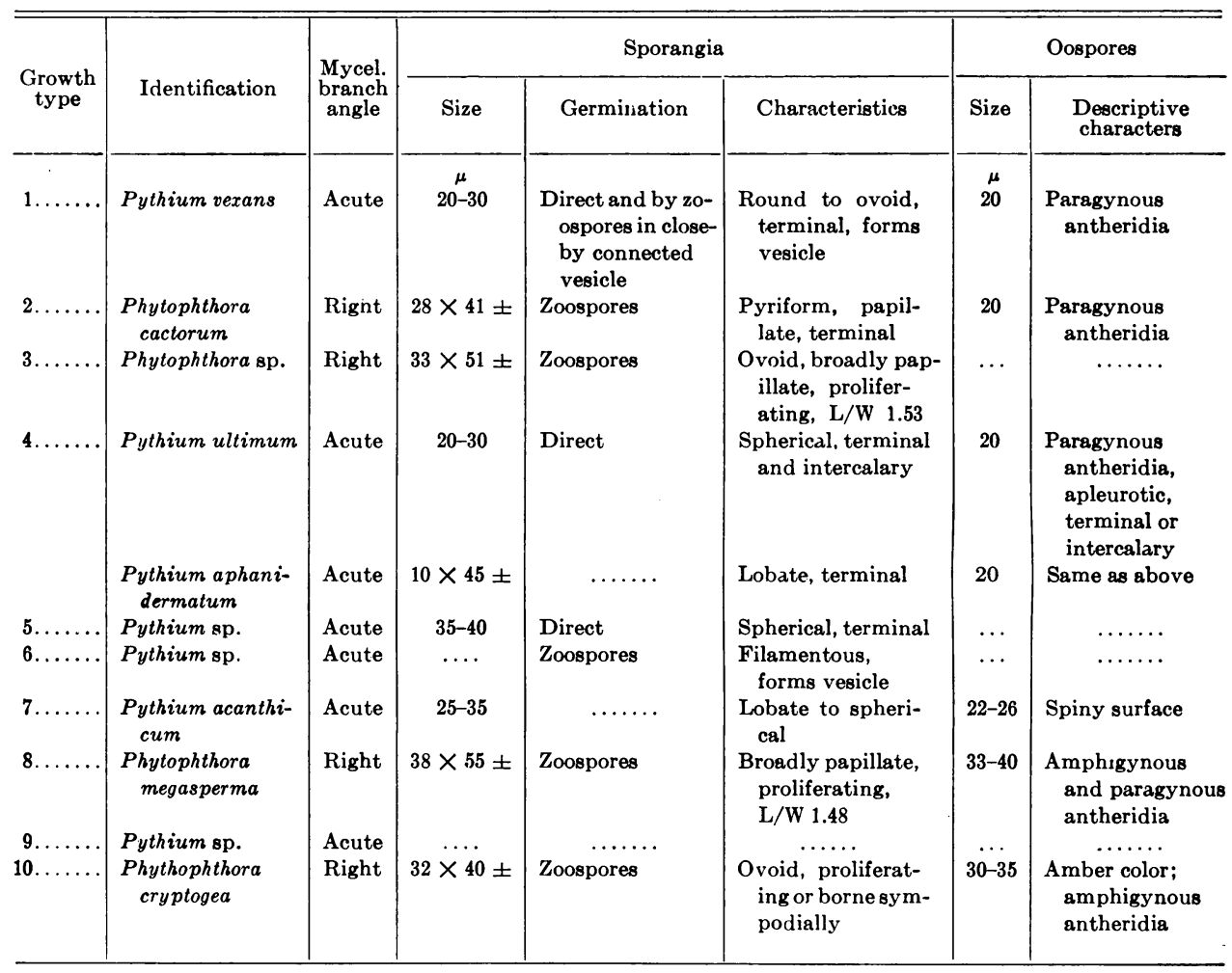

thicum Drechsl. by the echinulation of the oogonial wall and the presence of intercalary, subspherical sporangia, usually including a contiguous portion of hyphae (fig. 6). Typing characters were a sparse, frosty growth pattern (fig. 4), and the presence of the characteristic oospores.

$G T$-8. GT-8 had more aerial mycelium and a slightly larger colony on PDA than did GT-3 (figs. 3 and 4). These cultures could be identified as Phytophthora megasperma Drechsl., using the key and description of Waterhouse and Blackwell (1954). All isolates produced typical, smooth-walled oospores, 33 to $40 \mu$ in diameter, on dif plates (fig. 6, table 2). The antheridia, where a definite determination could be made, were invariably observed to be paragyn- ous. The attachment of the antheridium at the base of the oogonium adjacent to the oogonial stalk, as it occurs in this growth type, can produce a false appearance of amphigyny, and thus it was often very difficult to make a definite determination of this character. Proliferating, oval sporangia, which were morphologically similar to those of GT-3, averaged $38 \times 55 \mu$ (fig. 5). Hyphal swellings were sometimes observed in agar cultures. Diagnostic typing characters were colony growth pattern and the presence of the large, distinctive oospores in dif plates.

GT-9. The GT-9 cultures had a radially lobed colony pattern (fig. 4) and could not be induced to sporulate. These isolates were called a Pythium 
species because of the mycelial diameter, angle of branching, and cultural growth rate (table 1 ).

GT-10. A smooth, nonzonate colony of limited size (table 1, fig. 4) and the lack of fruiting on dif plates was characteristic of GT-10 cultures. Ovoid to pyriform, proliferating sporangia $32 \times$ $40 \mu$ were typically borne within the empty sporangial walls on alfalfa stems (fig. 6). The sporangiophores of this Phytophthora species were sometimes sympodially branched. These cultures were keyed to $P$. cryptogea after amber oospores 30 to $35 \mu$ in diameter were produced in mating trials with $P$. cinnamomi on lima bean agar.

Miscellaneous fungi. One culture of Phytophthora cinnamomi and 58 miscellaneous fungi were isolated. These isolates included phycomycetes with sterile mycelium or atypical spores and others which were lost to contamination.

The total number of isolates recovered of each growth-type is recorded in the last column on the right in table 3 . Analysis of isolation frequency in relation to pear-decline incidence, growthtype recovery, trap type, and monthly intervals was made from the punched card data.

\section{Comparison of amount and types of isolates from various traps}

Phytophthora isolates were recovered from pear and apple fruit traps more often than from lemon and avocado fruit or pear and apple seedlings (fig. 7 , table 3).

All the traps yielded a considerable number of Pythium isolates; however, pear fruit and seedlings were most effective in trapping Pythium isolates from California pear-orchard soils. Growth-type 4, largely Pythium ultimum, and GT-6, an unidentified Pythium species, were trapped most frequently in pear seedlings (table 3 ).

As mentioned earlier, avocado fruit traps were not used for the soil samples collected during the months of July through October, 1961, because the only satisfactory variety, Fuerte, was not available at that time. Pear seedlings were not used for soil samples collected during the months of April and May, 1961, and apple seedlings were not used for samples collected during the months of April through July, 1961. Pear and apple seedlings and avocado fruit probably would have shown much better performance compared to the pear, apple, and lemon fruit had they been used throughout the entire survey.

A more critical comparison can be made between the number of times Pythium and Phytophthora species were isolated from any given trap. Pear and apple seedlings and avocado fruit trapped many more Pythium than Phytophthora species isolates. Apple fruit yielded approximately the same number of Pythium and Phytophthora species isolates (fig. 7 , table 3 ).

Fig. 5 (opposite page). Fruiting structures of growth types 1 through 5 :

1. Pythium vexans: $a$. Oospore; $b$. Sporangium; $c$. Germination of zoospores from vesicle extruded from sporangium.

2. Phytophthora cactorum: a. Oospore and empty antheridium; $b$. Sympodially branched sporangia.

3. and 8b. Phytophthora sp. (GT-3) and P. megasperma: Proliferating sporangia common to both groups.

4. Pythium ultimum: a. Oospore and empty antheridium; $b$. Terminal sporangium; $c$. Intercalary sporangium.

4d. Pythium aphanidermatum: Lobate sporangium.

5. Pythium sp. (GT-5) : Sporangium. 

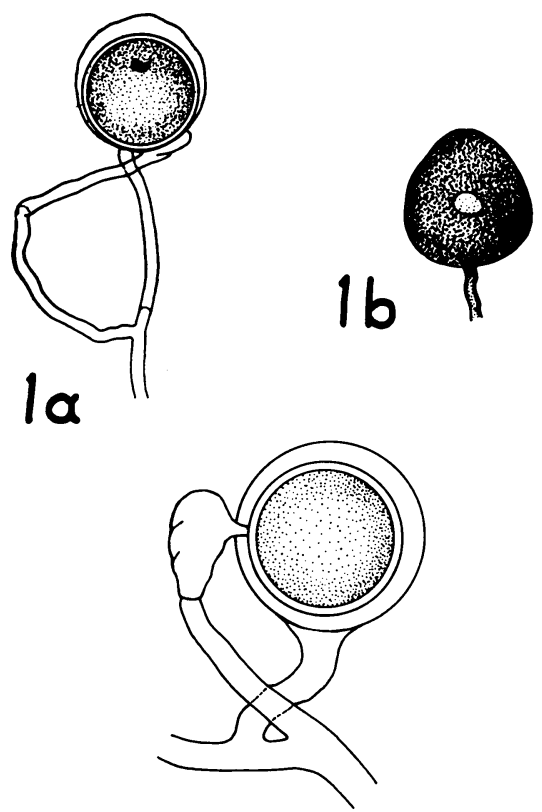

$2 \alpha$
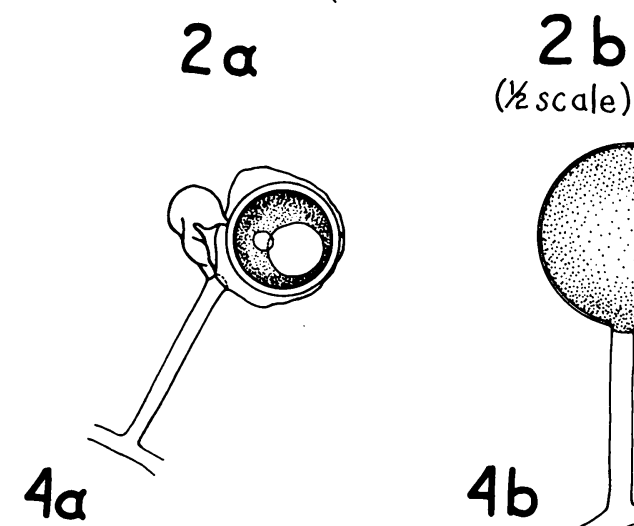

(1/2scale)
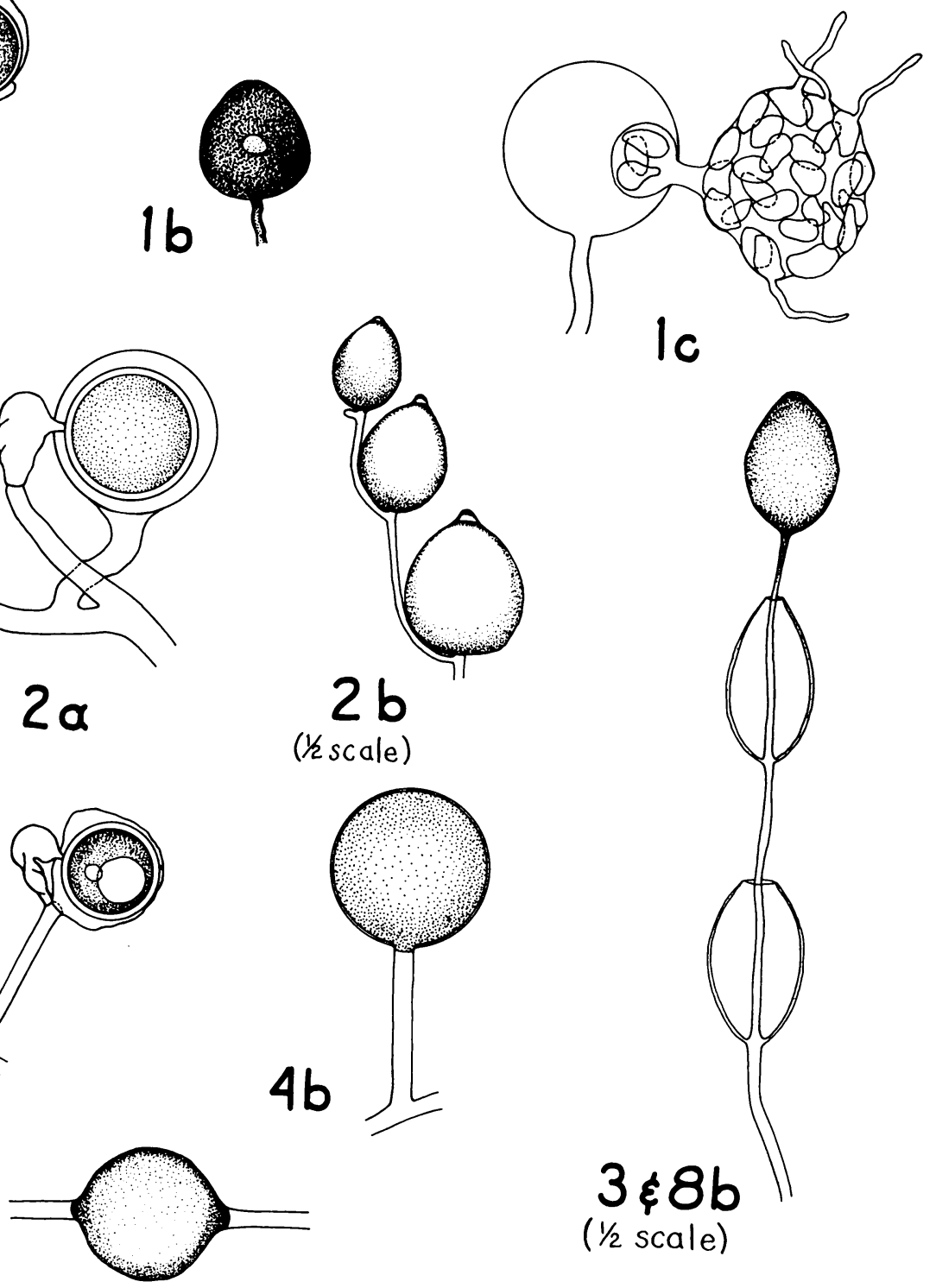

4c
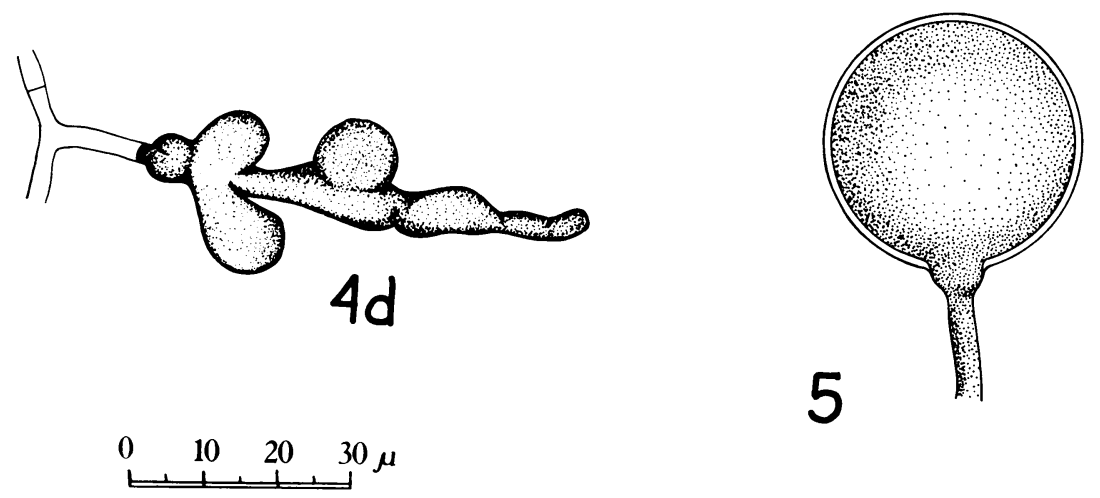
TABLE 3

COMPARATIVE EFFICIENCY OF SIX FRUIT AND SEEDLING TRAPS FOR THE ISOLATION OF PYTHIACEOUS FUNGI FROM PEAR-ORCHARD SOIL

\begin{tabular}{|c|c|c|c|c|c|c|c|c|}
\hline \multirow{3}{*}{$\begin{array}{c}\text { Growth } \\
\text { type }\end{array}$} & \multirow{3}{*}{ Identification } & \multicolumn{7}{|c|}{ Number of isolates from: } \\
\hline & & \multicolumn{4}{|c|}{ Fruit } & \multicolumn{2}{|c|}{ Seedlings } & \multirow{2}{*}{$\begin{array}{c}\text { All } \\
\text { traps }\end{array}$} \\
\hline & & Pear & Apple & Lemon & Avocado & Pear & Apple & \\
\hline $\begin{array}{l}1 \ldots \ldots \\
4 \ldots \ldots \\
5 \ldots \ldots \\
6 \ldots \ldots \\
7 \ldots \ldots \\
9 \ldots \ldots \ldots\end{array}$ & $\begin{array}{l}\text { Pythium vexans } \\
\text { P. ultimum and } \\
\quad \text { P. aphanidermatum } \\
\text { Pythium sp. } \\
\text { Pythium sp. } \\
\text { P. acanthicum } \\
\text { Pythium sp. }\end{array}$ & $\begin{array}{r}111 \\
373 \\
46 \\
59 \\
1 \\
9\end{array}$ & $\begin{array}{r}155 \\
\\
57 \\
150 \\
20 \\
6 \\
17\end{array}$ & $\begin{array}{r}45 \\
\\
208 \\
44 \\
47 \\
0 \\
8\end{array}$ & $\begin{array}{r}90 \\
96 \\
44 \\
66 \\
0 \\
9\end{array}$ & $\begin{array}{r}14 \\
431 \\
10 \\
84 \\
0 \\
0\end{array}$ & $\begin{array}{r}7 \\
140 \\
4 \\
56 \\
0 \\
2\end{array}$ & $\begin{array}{r}422 \\
1305 \\
298 \\
332 \\
7 \\
45\end{array}$ \\
\hline \multicolumn{2}{|c|}{ Miscellaneous fungi* } & 19 & 11 & 12 & 10 & 3 & 4 & 59 \\
\hline \multicolumn{2}{|c|}{ Total isolates per trap } & 1028 & 827 & 567 & 395 & 553 & 216 & 3586 \\
\hline
\end{tabular}

* These isolates include Phycomycetes with sterile mycelium, those with atypical spores, and those which have been lost in culture because of contamination.

TABLE 4

MONTHLY RECOVERY OF PYTHIACEOUS FUNGI FROM PEAR SOII.

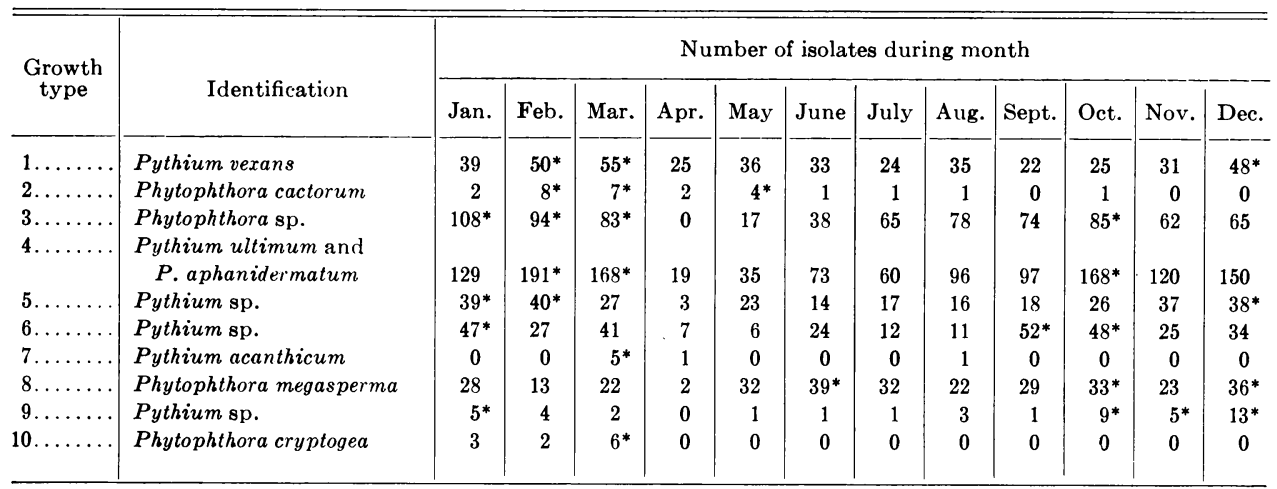

* Collected during months of greatest water-mold recovery.

Fig. 6 (opposite page). Fruiting structures of growth types 6 through 10 :

6. Pythium sp. (GT-6): $a$. Filamentous sporangium; $b$. Vesicle; $c$. Cleaved zoospores within vesicle.

7. Pythium acanthicum: $a$. Echinulate oospore and empty antheridium; $b$. Sporangium resting on short stalk; c. Sporangium resting on contiguous portion of hypha.

8. Phytophthora megasperma: a. Oospore and empty antheridium.

9. Pythium sp. (GT-9): No fruiting bodies depicted, since none were observed in these studies. 10. Phytophthora cryptogca: $a$. Proliferating sporangia; $b$. Sympodially branched sporangia. 

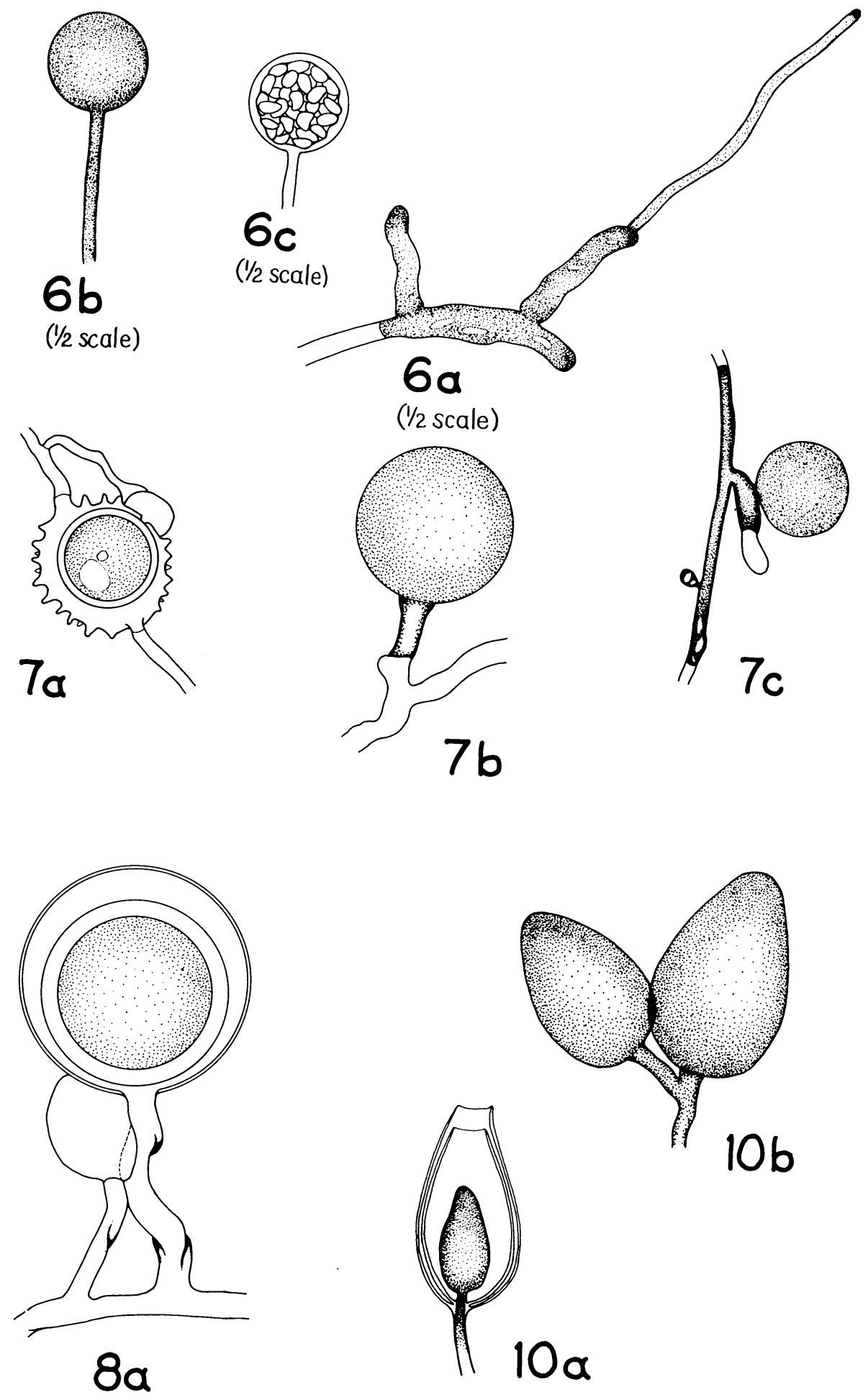

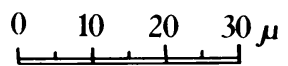




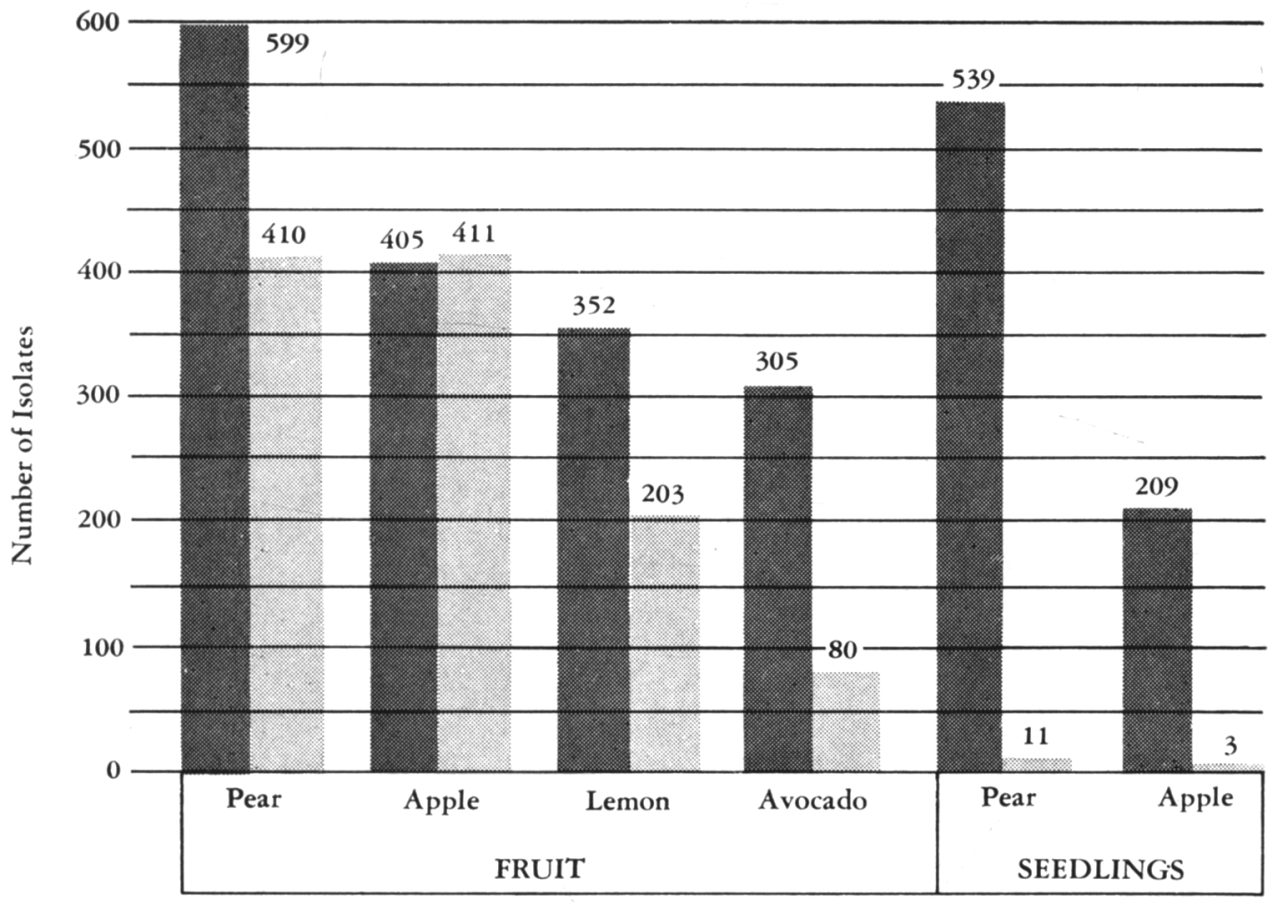

Trap Type

Pythium Isolates

Phytophthora Isolates

Fig. 7. Recovery of Pythium and Phytophthora species isolates from six different trap types.

\section{Seasonal variation of isolation frequency}

Great care was necessary in making an analysis of seasonal recovery frequency, since certain extraneous factors, such as the condition and age of the trap fruit, may exert a considerable effect. Data for the month of April, 1961, must also be considered as reflecting certain inadequacies in sampling and isolation techniques during the first month that soil samples were taken.

Early spring and winter were the most favorable periods for recovery of the water molds listed in this survey (table 4); however, a substantial recovery of all the major types was made throughout the year.

\section{Growth types in relation to orchard decline indexes}

1961 decline indexes were available for orchards in which two-thirds of the isolates were gathered. As mentioned earlier, these orchards were divided into three groups based on the severity of pear-decline damage as indicated by the decline indexes. The first group, designated as having light damage, included those orchards with decline indexes of 1 to 1.4 ; the second group, designated as having moderate damage, included those orchards with decline indexes of 1.4 to 1.9 ; and the third group, designated as having severe damage, included all orchards with decline indexes greater than 1.9. There were 689 isolates recovered from 
orchards in the first group, 902 from the second, and 398 from the third.

Phytophthora species (GT-2, GT-3, GT-8, and GT-10) were recovered less frequently in orchards where decline was most severe (fig. 8). However, recovery of Pythium species was directly correlated with the severity of decline damage. The recovery rate of $P$. vexans (GT-1) was nearly doubled (10.3 per cent to 19.0 per cent) and that of $P$. ultimum (GT-4) was increased by about two-thirds (20.6 per cent to 33.8 per cent) in those orchards in the group with severe damage as compared with those in the group with light damage (table 5).

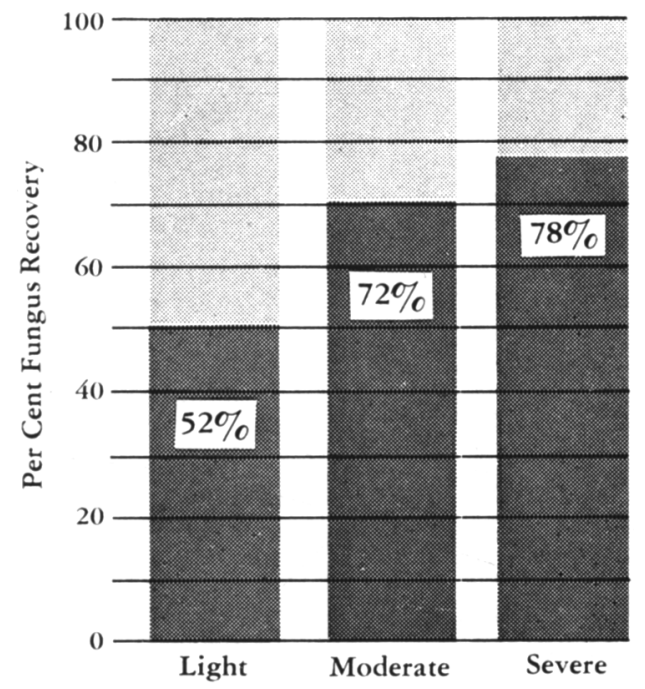

Severity of Decline Damage

Pythium Species : Phytophthora Species

Fig. 8. Relative per cent recovery of Pythium and Phytophthora isolates in relation to severity of pear-decline damage in California pear orchards.

\section{Growth-type isolation frequencies in California counties and their relation to county decline indexes}

The California counties from which soil samples were taken and the percentage of the soil samples from each county that yielded each growth-type are listed in table 6. Also indicated in this table are the 1961 decline indexes derived for each county by Rackham et al. (1964). Although the relationships between the county decline indexes and the frequencies with which the different growth-types were isolated in the counties is not as striking as when the orchard decline indexes are compared with the frequencies with which the growth-types were isolated from the orchards (figure 8 and table $5)$, there is a tendeney for them to be the same. The recovery of Pythium species tended to increase (and of Phytophthora species to decrease) as the county decline indexes increased.

\section{Pathogenicity tests in nutrient solutions}

All 27 Phytophthora cactorum (GT2) isolates produced root rot (fig. 9). One-fourth of these produced severe root rot, one-fourth produced moderate symptoms, and one-half produced light root rot.

All 11 Phytophthora cryptogea (GT10) isolates produced root rot which was identical to but generally more severe than symptoms produced by $P$. cactorum isolates. Five of these isolates produced severe root rot, five produced moderate root rot, and one produced light root rot. In two days, rot from the most virulent of these isolates spread 1 to $4 \mathrm{~cm}$ upward from the point of infection at the root tip (fig. 10).

All Phytophthora cactorum and $P$. cryptogea cultures were reisolated from pear roots with relative ease.

Growth type-1 (Pythium vexans), GT-3 (Phytophthora sp.), GT-4 (Pythium ultimum and $P$. aphanidermatum), GT-5 (Pythium sp.), and GT-6 (Pythium sp.) were reisolated occasionally from surface-sterilized roots on selective antibiotic agar; however, these cultures produced only slight evidence of root rot.

GT-7 (Pythium acanthicum), GT-8 


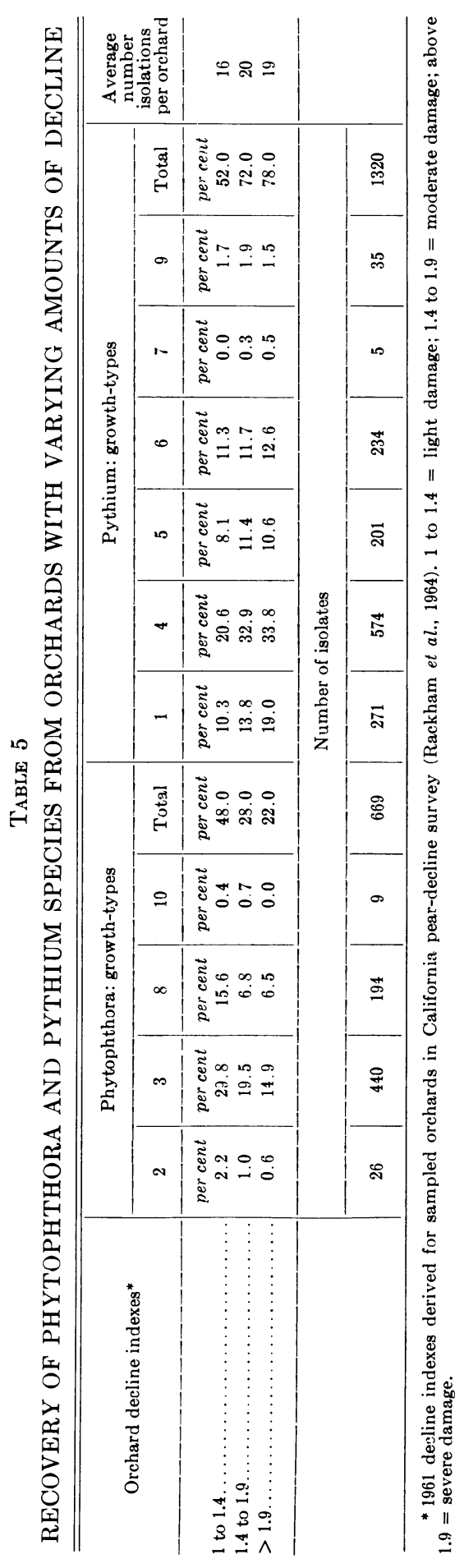




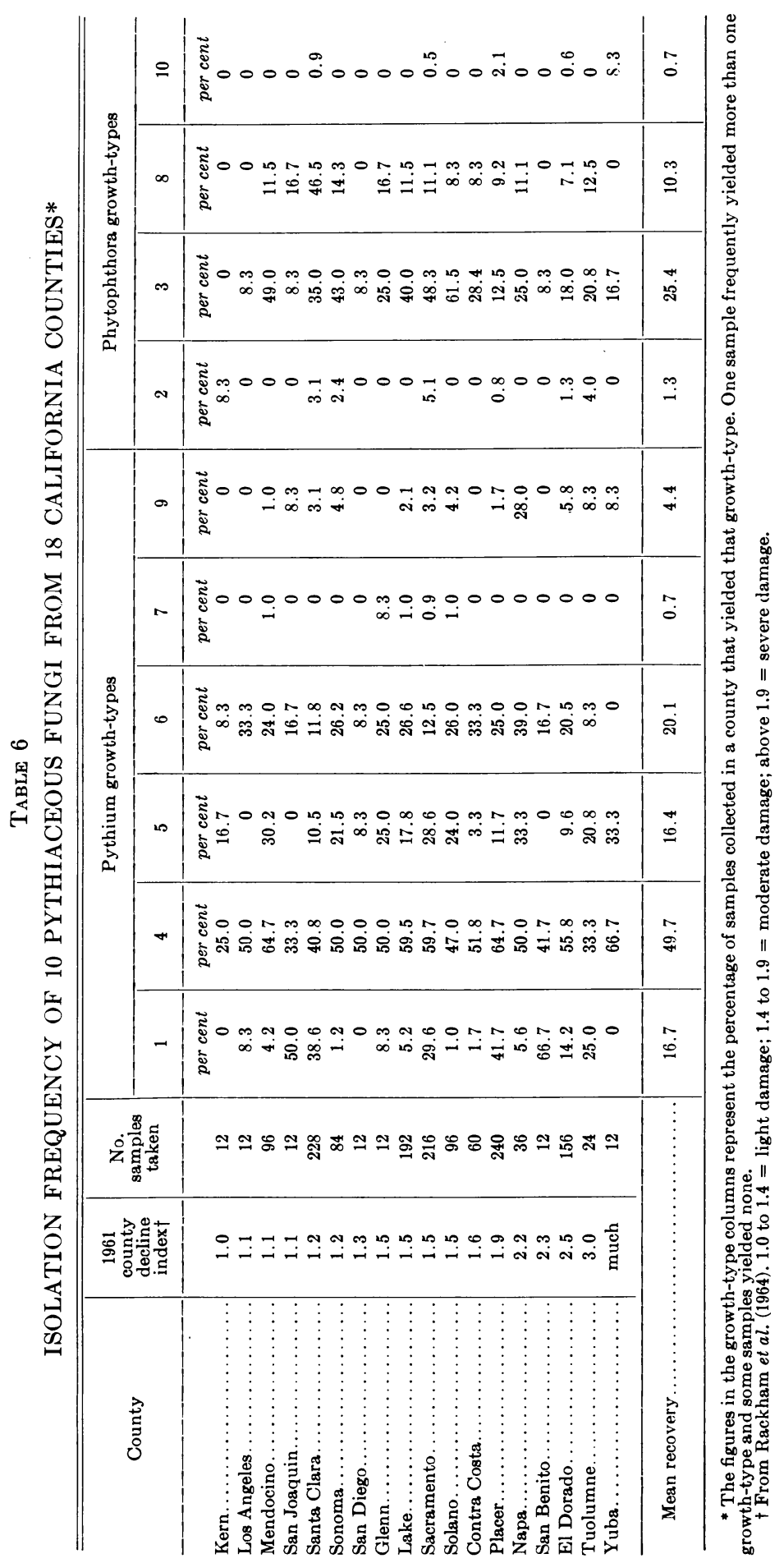




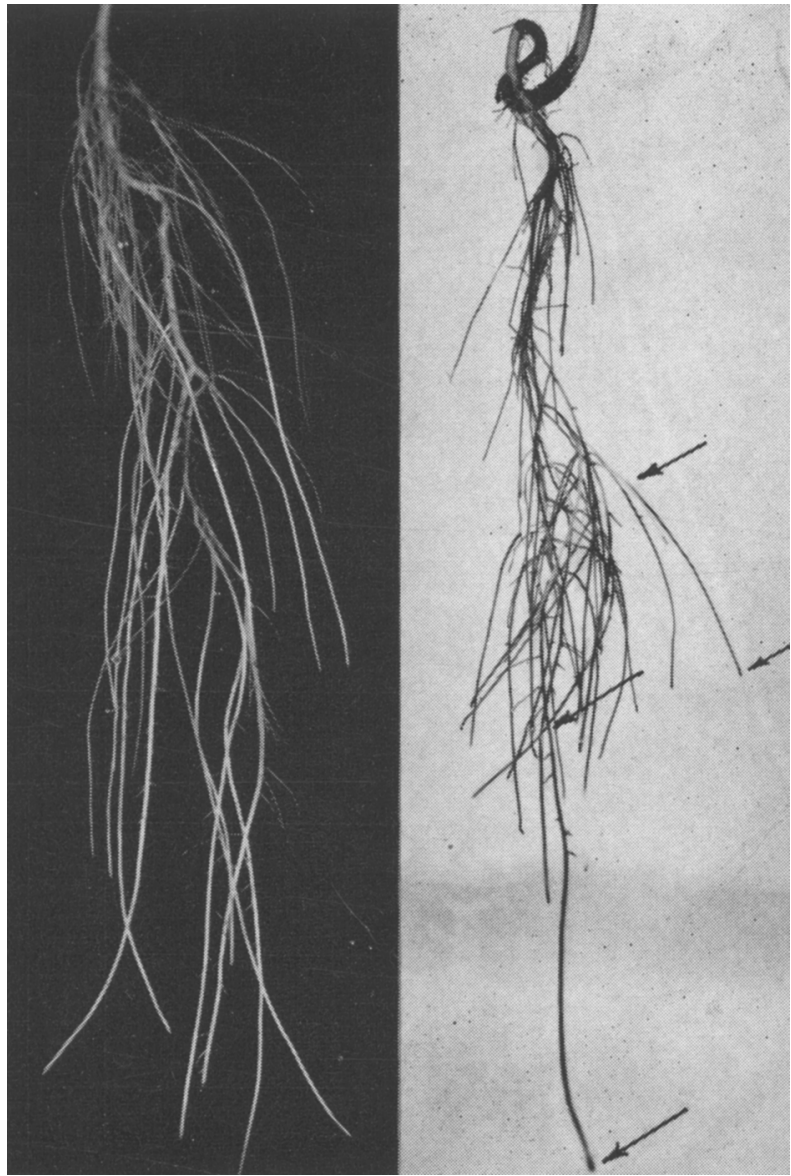

Fig. 9. Winter Nelis pear roots seven days after inoculation with Phytophthora cactorum in Hoagland's solution (control: left; inoculated: right). Note fewer and shorter roots with necrotic lesions (between arrows) in inoculated as compared with the control.

(Phytophthora megasperma), GT-9 (Pythium sp.) and the one isolate of Phytophthora cinnamomi could not be reisolated from inoculated pear seedling roots and produced no lesions or root damage.

\section{Pear susceptibility}

The Winter Nelis pear root system grew more vigorously than the Pyrus serotina; however, the hypercotyls of the $P$. serotina had grown larger than those of the Winter Nelis at the time of inoculation. The more vigorously growing Winter Nelis roots were con- sistently more susceptible to Phytophthora root rot than were the Pyrus serotina roots at this stage of growth (fig. 10).

\section{Pathogenicity tests in soil}

None of the isolates produced extensive root rot in greenhouse soil tests. However, GT-4 (Pythium ultimum and $P$. aphanidermatum) and GT-6 (Pythium sp.), when compared to control plants, produced a slight amount of root rot after the pots were placed in three inches of free water for seven days after inoculation. 


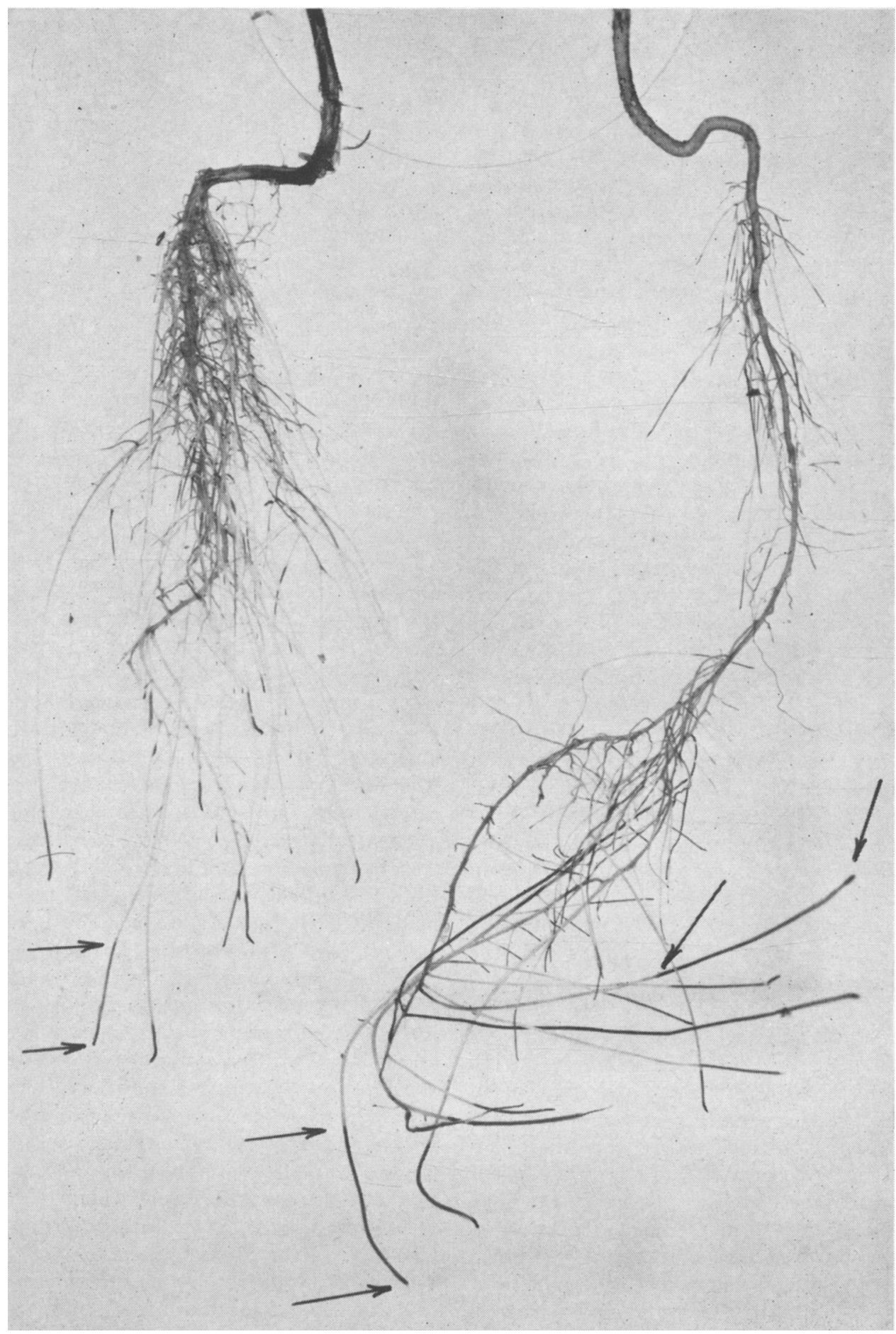

Fig. 10. Phytophthora cryptogea root rot two days after inoculation of Pyrus serotina Rehd. (left) and of Pyrus communis L., variety Winter Nelis (right). Plants were grown in Hoagland's solution. Note root rot between arrows. 


\section{DISCUSSION}

At the onset of pear-decline investigations in 1959 , collapsed trees which were uprooted consistently showed rotted rootlets. It was decided by University of California and State Department of Agriculture officials that much information could be gained by conducting a one-year soil fungus survey in the pear orchards which were being rated for decline. Initially, fungi were included as possible causes of the disease. Pythiaceous fungi were selected as the most probable agents in the decay of pear roots.

The identity of the various growth types recognized in this study was investigated throughout the typing process. Routine observations during the typing process provided much evidence; however, detailed investigations were sometimes necessary to provide information on important taxonomic criteria. In some cases we were not successful in establishing the information necessary for positive species identification. It was recognized that identification of Pythium and Phytophthora species is a difficult task and that the taxonomy of the whole group is a matter of some dispute. Identification of these species was made by the authors using criteria available in the literature.

The generally low nutrient level of the dif plates, while favorable for fruiting, retarded vegetative growth and facilitated direct examination of the cultures with a compound microscope. Fruiting bodies were most frequently observed on the translucent water agar in the vicinity of the lima bean agar disc. Occasionally the oatmeal or cornmeal agars produced sporulation not otherwise observable. The sporangia of GT-3, 8, and 10 were rarely observed in agar culture, but were formed regularly on infested alfalfa stems placed in tap water or
Hoagland's solution. This technique greatly facilitated the identification of the growth types.

The data presented in this paper indicate that pythiaceous fungi are not the primary agents in the cause of pear decline and are in accord with the conclusion of Cameron (1962) in this regard. However, root damage caused by these fungi is, very likely, one of many stress factors contributing to the rapidity of pear-decline symptom development. Any agent that weakens or destroys the water-absorbing root system of a tree places that tree in jeopardy when a sudden demand is made on the root system for a large supply of water. The aerial portions of the tree that need and do not receive the additional water are damaged and the final demise of the tree is hastened.

Pythium species were isolated most often from: (1) seedling traps (table 3 ); and (2) orchards with the greatest amount of decline damage (table 5). The first situation correlates with the reputation of various Pythium species as seedling pathogens. The seedlings were young; therefore these results may well be evidence of a damping-off phenomenon. The second situation might suggest that Pythium species are the primary cause of pear decline; however, pathogenicity studies on pear seedlings indicated only mild pathogenicity by any of the Pythium species collected in the survey. There is strong evidence that true pear decline is the result of necrosis of phloem tissue, primarily at the graft union, caused by either a toxin injected into the trees by the pear psylla (Lindner et al., 1962), a graft-transmissible factor, presumably a virus (Shalla et al., 1963), or a combination of both. The high occurrence of Pythium species in orchards with high decline indexes probably reflects the important role of these fungi in the decay of pear 
roots already weakened or killed as a result of phloem necrosis induced by insect toxin and/or virus.

Severe root rot was caused by isolates of Phytophthora cactorum (Leb. and Cohn) Schroet. and P. cryptogea in Hoagland's solution tests; however, the same isolates produced only slight root rot in potted soil experiments. This might indicate the importance of good irrigation practices, particularly with young trees, to eliminate the prolonged presence of free water, which enhances the infection by Phytophthora spp.

The frequency of Phytophthora spp. isolation decreased as orchard and county pear-decline indexes increased (tables 5 and 6 ). One might conclude that the Phytophthora species required healthier roots to support their population, resulting possibly in more frequent isolation from newly infected roots than from those which were more thoroughly rotted. Also, the presence of rapidly growing saprophytic fungi in the dead root tissue very likely reduced the frequency of Phytophthora spp. isolation.

The high numbers of Phytophthora species recovered from the various fruit traps' (table 3 ) are not surprising in view of the successful use of fruit by other workers (Campbell, 1949; McIntosh, 1960; Newhook, 1959; Tucker, 1931; Zentmyer et al., 1960) for the trapping of water molds.

\section{SUMMARY}

A cooperative statewide survey to determine the occurrence of certain plant pathogens in California pear soils and their relation to pear decline was conducted for a 12-month period beginning April, 1961. The most extensive survey of its kind, it necessitated the cooperation of growers and of research, extension, and regulatory personnel. This paper reports on the occurrence of Phytophthora and Pythium species in California pear orchards with various degrees of the malady.

A total of 3,586 isolates were obtained, including 1,195 of Pythium ultimum Trow, 110 of $P$. aphanidermatum Edson, 422 of $P$. vexans de Bary, 7 of $P$. acanthicum Drechsl., and 675 of three unidentified Pythium species. Phytophthora species included 311 of P. megasperma Drechsl., 769 of an unidentified Phytophthora sp. which had certain characteristics resembling $P$. megasperma, 27 of $P$. cactorum (Leb. and Cohn) Schroet., 11 of P. cryptogea Pethybr. and Laff. and 1 of $P$. cinnamonii Rands. In addition, 58 miscel- laneous fungus cultures were recovered. The frequency of Pythium spp. isolation increased as the severity of peardecline damage increased, while the total number of Phytophthora spp. isolates per orchard decreased as peardecline damage severity increased.

Pear and apple seedlings trapped a high number of Pythium spp. isolates, while very few Phytophthora spp. were trapped in seedlings. Phytophthora spp. isolates were trapped most often in pear and apple fruit. Lemon and avocado fruit yielded a fair number of both genera.

In the greenhouse pathogenicity tests, isolates of $P$. cactorum and $P$. cryptogea were found to be pathogenic on Pyrus communis L. hort. var. Winter Nelis, and Pyrus serotina Rehd. seedlings. These pathogens were found infrequently in the survey and it was concluded that Pythiaceous fungi are not the primary cause of pear decline. Representative isolates of all other growth types in this study were not pathogenic to pear roots. 


\section{ACKNOWLEDGMENT}

The authors wish to extend their appreciation to the many county agricultural commissioners, University of California farm advisors, and laboratory and field helpers, too numerous to mention, who helped expedite this portion of the California pear-decline investigations. They also wish to thank H. J. O'Reilly, Extension Plant Pathologist, and T. A. Shalla, chairman of the California pear-decline research committee, for much of the planning and initial work of this research and for their review of this report. The authors acknowledge their indebtedness to $G$. Douglas Barbe for preparing the drawings used to illustrate this report.

\section{LITERATURE CITED}

Anderson, E. J.

1951. A simple method for detecting the presence of Phytophthora cinnamomi Rands in soil. Phytopathology 41: 187-89.

\section{ANONYMOUS}

1942-1963. Distribution maps of plant diseases. Commonwealth Mycological Institute Map Nos. $35,47,70,157,174,203,280,281$, and 302 .

1960. Index of plant diseases in the United States. U. S. Dept. Agr., Agr. Handbook No. 165. $531 \mathrm{pp}$.

Baldacci, E., G. Catoni, R. Ciferri, L. Marimpietri, and E. Refatti

1949. Relazione sui dati e le esperienze circa la "Moria" del peronella Venezia Tridentina (Trentino ed Alto Adige). Notizario Sulle Malattie Delle Piante. No. 4 (Sept., 1949). $51 \mathrm{pp}$.

BlaCKWELI, ElizaBeTH M.

1949. Terminology in Phytophthora. Commonw. Mycol. Inst., Mycol. Papers, No. 30. 24 pp.

Cameron, H. Ronald

1960. Infection of pear roots with Phytophthora cinnamomi. (Abstr.) Phytopathology 50:630.

1962. Susceptibility of pear roots to Phytophthora. Phytopathology 52:1295-97.

CAMPBell, W. A.

1948. Phytophthora cinnamomi associated with the roots of littleleaf-diseased shortleaf pine. Plant Disease Rptr. $32: 472$.

1949. A method of isolating Phytophthora cinnamomi directly from soil. Plant Disease Rptr. 33:134-35.

Chiarappa, Luigi

1959. The root rot complex of Vitis vinifera in California. Phytopathology 49:670-74.

DARley, Ellis F., and Wesley D. Wilbur

1953. Phytophthora rot of Washington palms. Phytopathology 43:469-70.

ECKerT, J. W., and P. H. TsAo

1960. A preliminary report on the use of pimaricin in the isolation of Phytophthora spp. from root tissues. Plant Disease Rptr. 44:660-61.

1962. A selective antibiotic medium for isolation of Phytophthora and Pythium from plant roots. Phytopathology 52:771-77.

FAWCETT, H. S.

1913. Two fungi as causal agents in gummosis of lemon in California. Calif. State Commr. Hort. Mon. Bul. 2(8):601-17.

1915. The known distribution of Pythiacystis citrophthora and its probable relationship to Mal da Gumma of citrus. Phytopathology 5:66-67.

1916. A Pythiacystis on avocado trees. Phytopathology $6: 433-35$.

1920. Pythiacystis and Phytophthora. Phytopathology 10:397-99.

1936. Citrus diseases and their control. McGraw-Hill Book Co., Inc., New York, N.Y. 656 pp.

French, A. M., B. F. Lownsbery, S. M. Ayoub, A.C. Weiner, and N. El-Gholl

1964. Pythiaceous fungi and plant-parasitic nematodes in California pear orchards. II: Incidence and distribution of parasitic nematodes in orchard soils. Hilgardia 35 (21): 603-10.

Hoagland, D. R., and D. I. Arnon

1950. The water culture method for growing plants without soil. Calif. Agr. Expt. Stat. Circ. 347 (Revised). $32 \mathrm{pp}$. 


\section{Hunt, T. Francis}

1921. Pythiacystis "brown rot" affecting deciduous trees. Calif. Dept. Agr. Monthly Bul. $10(4): 143-45$.

KLOTZ, L. J., and T. A. DEWoLfE

1958. Techniques for isolating Phytophthora spp. which attack citrus. Plant Disease Rptr. 42:675-76.

1960. The production and use of zoospore suspensions of Phytophthora spp. for investigations on diseases of citrus. Plant Disease Rptr. 44:572-73.

Klotz, L. J., T. A. DeWolfe, and Po-Ping Wong

1958. Decay of fibrous roots of citrus. Phytopathology 48:616-22.

KLotz, L. J., and V. P. SokolofF

1943. The possible relation of injury and death of small roots to decline and collapse of citrus and avocado. Calif. Citrog. 28:86-87.

Lindner, R. C., E. C. Burts, and N. R. Benson

1962. A decline condition in pears induced by pear psylla. Plant Disease Rptr. 46:59-60.

Lownsbery, B. F., J. T. MITCHELL, and S. M. PARACER

1964. Pythiaceous fungi and plant-parasitic nematodes in California pear orchards. III: Effect of reduction in nematode populations by soil fumigation on subsequent growth of pear seedlings. Hligardia 35(21):611-14.

McINTosh, D. L.

1960. The infection of pear rootlets by Phytophthora cactorum. Plant Disease Reptr. 44: 262-64.

Middleton, JoHn T.

1943. The taxonomy, host range and geographic distribution of the genus Pythium. Mem. Torrey Bot. Club 20(1):1-171.

1952. Generic concepts in the Pythiaceae. Tijdschrift over Plantenziekten 58:226-35.

MILLER, P. A.

1942. Phytophthora crown rot of loquat. Phytopathology 32:404-09.

NEWHOOK, F. J.

1957. A Pythium disease of pear trees. New Zealand Jour. Sci. and Technol. 38:533-38.

1959. The association of Phytophthora spp. with the mortality of Pinus radiata and other conifers: I. Symptoms and epidemiology in shelterbelts. New Zealand Jour. Agr. Res. $2(4): 808-43$.

Nichols, Carl W., Henry Schneider, H. J. O'Reilly, Thomas A. Shalla, and W. H. Griggs

1960. Pear decline in California. Calif. Dept. of Agr. Bul. 49:186-92.

Rackham, R. L., D. E. Alderman, H. J. O'Reilly, and CarL W. Nichols

1964. Pear decline incidence and severity in California in 1960, 1961 and 1962. Plant Disease Rptr. 48:204-05.

Shalla, T. A., Luigi Chiarappa, E. C. Blodgett, E. Refatti, and E. Baldacci

1961. The probable coidentity of the moria disease of pear trees in Italy and pear decline in North America. Plant Disease Rptr. 45:912-15.

Shalla, T. A., Luigi Chiarappa, and T. W. Carroll

1963. A graft-transmissible factor associated with pear decline. Phytopathology 53:366-67.

SMITH, C. O., and J. T. BARRETT

1930. Some inoculations with Phytophthora-like fungi. (Abstr.) Phytopathology 20:849-50.

SMith, ElizabeTh H.

1915. Pythiacystis infection of deciduous nursery stock. Phytopathology 5:317-22.

SMITH, RALPH E.

1941. Diseases of fruits and nuts. Calif. Agr. Ext. Ser. Circ. 120. 168 pp.

SMITH, RALPH E., and ElizaBeTH H. SMith

1925. Further studies on Pythiaceous infection of deciduous fruit trees in California. Phytopathology 15:389-404.

SPRAGUE, RODERICK

1957. Fungi isolated from roots and crowns of pear trees. Plant Disease Rptr. 41:74-76.

SutherLaNd, C. F., and F. J. NewhoOK

1959. The association of Phytophthora spp. with mortality of Pinus radiata and other conifers. II. Influence of soil drainage on disease. New Zealand Jour. Agr. Research 2:844-58.

Torgeson, D. C.

1951. The Phytophthora root rots of Chamaecyparis lawsoniana Parl. (Abstr.) Phytopathology 41:944.

Torgeson, D. C., Roy A. Young, and J. A. Milbrath

1954. Phytophthora root rot diseases of Lawson cypress and other ornamentals. Oregon State College Agr. Expt. Stat. Bul. 537. 11 pp. 
TUCKER, C. M.

1931. Taxonomy of the genus Phytophthora de Bary. Univ. of Mo., Coll. of Agr., Agr. Expt. Stat. Res. Bul. 153. 208 pp.

1933. The distribution of the genus Phytophthora. Univ. of Mo., Coll. of Agr., Agr. Expt. Stat. Res. Bul. 184. 80 pp.

Tucker, C. M., and J. A. Milbrath

1942. Root rot of Chamaecyparis caused by a species of Phytophthora. Mycologia 34:94-103.

WAGER, VINCENT A.

1942a. Phytophthora cinnamomi and wet soil in relation to the dying-back of avocado trees. Hilgardia 14(9):519-32.

$1942 b$. Pythiaceous fungi on citrus. Hilgardia 14(9):535-48.

WATERHouse, Grace M.

1956. The genus Phytophthora. Commonw. Mycol. Inst., Misc. Publ. No. 12. 120 pp.

Waterhouse, Grace M., and Elizabeth M. Black Well

1954. Key to the species of Phytophthora recorded in the British Isles. Commonw. Mycol. Inst., Mycol. Papers, No. 57. 9 pp.

Woodridge, C. G., E. C. BlodgetT, and T. O. Diener

1957. Pear decline in the Pacific Northwest. Plant Disease Rptr. 41:569-72.

Zentmyer, George A., J. D. Gilpatrick, and W. A. Thorn

1960. Methods of isolating Phytophthora cinnamomi from soil and host tissue. Phytopathology $50: 87$.

Zentmyer, GeOrge A., and SterLing J. Richards

1952. Pathogenicity of Phytophthora cinnamomi to avocado trees and the effect of irrigation on disease development. Phytopathology 42:35-37. 
Pear fruit and pear and apple seedlings trapped more Pythium spp. than the fruit of apple, lemon, and avocado, while few Pbytophthora spp. were trapped in seedlings. Phytophtbora spp. isolates were trapped most often in pear and apple fruit. Lemon and avocado fruit yielded a fair number of both genera.

II. Plant-parasitic nematodes of various types are prevalent in the upper root zone of pear trees in California. Monthly samplings over a 12-month period, from the same 126 orchards mentioned above, showed that the dagger nematode Xiphinema americanum and the pin nematode Paratylenchus bamatus occurred in more than 90 per cent of the orchards and in all pear-growing areas of the state. Other nematodes frequently found were species of Tylenchorbynchus, Pratylenchus, Helicotylencbus, Meloidogyne, and Criconemoides. No direct relationship was indicated between pear decline and nematodes in orchard soils.

III. Reduction of populations of pin nematodes, spiral nematodes, and stunt nematodes in orchard soil by fumigation with ethylene dibromide did not improve the growth of Bartlett or Oriental pear seedlings. The results suggest that these nematodes are not an important factor limiting growth of pears in California. 
The journal HILGARDIA is published at irregular intervals, in volumes of about 650 to 700 pages. The number of issues per volume varies.

Single copies of any issue may be obtained free, as long as the supply lasts; please request by volume and issue number from:

$$
\begin{aligned}
& \text { Agricultural Publications } \\
& \text { University Hall } \\
& \text { University of California } \\
& \text { Berkeley, California } 94720
\end{aligned}
$$

The limit to nonresidents of California is 10 separate titles. The limit to California residents is 20 separate titles.

The journal will be sent regularly to libraries, schools, or institutions in one of the following ways:

1. In exchange for similar published material on research.

2. As a gift to qualified repository libraries only.

3. On a subscription basis $-\$ 7.50$ a year paid in advance. All subseriptions will be started with the first number issued during a calendar year. Subscribers starting during any given year will be sent back numbers to the first of that year and will be billed for the ensuing year the following January. Make checks or money orders payable to The Regents of The University of California; send payment with order to Agricultural Publications at above address. 